\title{
Importance of endogenous prostaglandins for the toxicity of cyclosporin A to rat endocrine and exocrine pancreas?
}

\author{
M Rünzi, B M Peskar, J v Schönfeld, M K Müller
}

\begin{abstract}
Previous work has shown that cyclosporin $A$ is toxic to the endocrine and exocrine pancreas. The aim of this study was to examine whether endogenous eicosanoids play a role in controlling cyclosporin A induced toxicity. Rats were treated for eight days with indomethacin ( $2 \mathrm{mg}$ ) $\mathrm{kg}$, twice daily) in addition to cyclosporin A (5 or $10 \mathrm{mg} / \mathrm{kg}$ daily). Effects of drug treatments on exocrine (as assessed by amylase and protein secretion into the pancreatic juice) and endocrine (as assessed by the glucose dependent insulin release) pancreatic functions, and pancreatic formation of prostaglandins and thromboxane were evaluated. Treatment with cyclosporin $A$ in the doses used did not inhibit eicosanoid formation by the pancreatic tissue ex vivo. Indomethacin caused significant inhibition of pancreatic formation of prostaglandin E2, 6k prostaglandin $F 1 \alpha$ and thromboxane B2. Combined treatment with indomethacin and cyclosporin $A(5$ or $10 \mathrm{mg}$ ) $\mathrm{kg}$ ) augmented cyclosporin $A$ induced pancreatic toxicity with further impairment of insulin release, amylase secretion, and pancreatic juice protein content, but did not result in more pronounced inhibition of pancreatic eicosanoid formation. The increased toxicity of the combined treatment was, however, associated with raised cyclosporin A whole blood concentrations. The data suggest that the potentiation of pancreatic toxicity of cyclosporin A observed during coadministration of indomethacin is not the result of suppression of endogenous pancreatic eicosanoid biosynthesis, but more likely results from altered cyclosporin A pharmacokinetic which may be caused by an interference of indomethacin with the hepatic cytochrome P-450 dependent monooxygenase involved in cyclosporin A metabolism. The possibility that coadministration of non-steroidal antiinflammatory drugs aggravates toxic effects in cyclosporin A treated patients should be considered.

(Gut 1992; 33: 1572-1577)
\end{abstract}

Cyclosporin A is a unique cyclic undecapeptide of fungal origin with potent immunosuppressive properties used to prevent the rejection of transplanted organs and to treat autoimmune diseases.' This drug has a narrow therapeutic window between inadequate immunosuppression and toxicity. ${ }^{2}$ The best known clinical side effects of cyclosporin A are nephrotoxicity and hepatotoxicity. ${ }^{3+}$ We have recently shown in rat pancreas that adverse effects include pancreatic toxicity. ${ }^{5}$ Chronical application of cyclosporin A in immunosuppressive doses caused dose dependent impairment of endocrine and exocrine pancreatic functions. In addition, it has been shown that cyclosporin $\mathrm{A}$ induced toxicity in rats corresponds with severe degranulation and hydropic degeneration of islet B-cells ${ }^{6}$ and a decrease in pancreatic insulin content and release. ${ }^{7}$ Concomitant administration of prostaglandins partially alleviated cyclosporin A induced nephrotoxicity. ${ }^{89}$ In addition we have recently shown that in rats treatment with a synthetic prostaglandin El analogue (Rioprostil) protects the pancreas against cyclosporin A induced damage. ${ }^{10}$

This study was designed to investigate the role of endogenous eicosanoids in the sensitivity of endocrine and exocrine pancreatic cells against the toxic effects of cyclosporin A. Depletion of pancreatic eicosanoids was achieved by use of the cyclooxygenase inhibitor, indomethacin.

\section{Methods}

\section{ANIMALS}

Male Wistar rats (mean body weight $300 \mathrm{~g}$ ), housed under conditions of constant temperature and a 12 hour lighting cycle, were used for the study. They were allowed free access to food (standard diet purchased from Altromin, Germany) and water. Before operation, the rats were fasted for 18 hours with free access to water and then anaesthetised with pentobarbital (60 $\mathrm{mg} / \mathrm{kg}$, intraperitoneally).

\section{MEDICATION}

Groups of 10-12 rats received the following drug treatments: (i) $5 \mathrm{mg} / \mathrm{kg}$ or $10 \mathrm{mg} / \mathrm{kg}$ cyclosporin A intragastrically once daily; (ii) $2 \mathrm{mg} / \mathrm{kg}$ indomethacin subcutaneously twice daily; (iii) $2 \mathrm{mg}$ / $\mathrm{kg}$ indomethacin subcutaneously twice daily in addition to 5 or $10 \mathrm{mg} / \mathrm{kg}$ cyclosporin A intragastrically once daily.

Indomethacin (Merck, Sharp and Dohme, Germany) was suspended in saline. Cyclosporin A (Sandimmun ${ }^{\circledR}$; Sandoz, Switzerland) in pure olive oil was administered intragastrically using a metal feeding tube. Controls were treated with the corresponding vehicles (saline subcutaneously and/or olive oil intragastrically). Drugs or vehicles were administered for eight days. Pancreatic perfusion experiments and incubation experiments to determine pancreatic eicosanoids formation were performed on day 9 . In cyclosporin A treated rats whole blood concentrations of cyclosporin A were determined 24 
hours after the last dose applied of cyclosporin A. Pancreatic eicosanoid formation was determined about 18 hours after the last administration of cyclosporin A and four hours after the last dose of indomethacin.

\section{OPERATION}

The isolated arterially perfused rat pancreas model was used to evaluate effects on exocrine and endocrine pancreatic functions. Briefly, the perfused preparation consisted of pancreas with a small remnant of duodenum according to the method as described elsewhere." The pancreas was perfused in situ through the superior mesenteric artery and the coeliac trunc at a constant flow of $4 \mathrm{ml} /$ minute without recirculation. The vascular effluent was collected in one minute fractions through the portal vein. The exocrine secretions were collected in 10 minute fractions through the cannulated pancreatic duct.

\section{PERFUSATES AND TEST SOLUTIONS}

The perfusate consisted of Krebs-Ringer bicarbonate buffer containing $\mathbf{0} \cdot 2 \%$ bovine serum albumin (Serva, Germany), 3\% dextran T 70 (Pharmacia, Germany), 7.9 or $15.8 \mathrm{mmol} / \mathrm{l}$ glucose, gassed with $95 \% \mathrm{O}_{2}-5 \% \mathrm{CO}_{2}$ to achieve a final $\mathrm{pH}$ of $7 \cdot 4$. The perfusion rate was $4 \mathrm{ml}$ minute with a perfusion pressure between 50 and $60 \mathrm{~cm} \mathrm{H}_{2} \mathrm{O}$.

The preparation was equilibrated by perfusion for 15 minutes with a buffer containing $7 \cdot 9$ $\mathrm{mmol} / \mathrm{l}$ glucose. After the equilibration period the perfusion medium was changed to buffer containing $15.8 \mathrm{mmol} / \mathrm{l}$ glucose and sampling started for a further $\mathbf{3 0}$ minute period. Synthetic cholecystokinin-8 $(100 \mathrm{pg} / \mathrm{ml}$ final concentration; Sigma, Germany) was additionally infused over the last 20 minutes of the sampling period at a constant flow of $0.2 \mathrm{ml} /$ minute to stimulate the exocrine pancreas. Infusion of cholecystokinin-8 did not change the perfusion pressure.

\section{ASSESSMENT OF PANCREATIC EICOSANOIDS} FORMATION

The pancreata were carefully removed and cut into fragments of $2-5 \mathrm{mg}$ wet weight. The fragments were blotted, weight and tissue aliquots of $100 \mathrm{mg}$ were immediately incubated in $1.0 \mathrm{ml}$ of oxygenated Tyrode solution at $37^{\circ} \mathrm{C}$ for 10 minutes. Release of prostaglandin E2, 6k prostaglandin $F 1 \alpha$, and thromboxane $B 2$ into the incubation media was determined radioimmunologically as described previously. ${ }^{12}$ Validation experiments have ascertained that standard prostanoids added to aliquots of pancreatic tissue media are recovered quantitatively. Furthermore, thin layer chromatography has shown that the immunoreactivity released into pancreatic tissue incubation media co-chromatographs exclusively with the corresponding standard prostanoids. were determined by a specific radioimmunoassay as described elsewhere." Pancreatic juice volume was sampled in 10 minute collection periods and the total amount collected over a 10 minute period was defined as pancreatic volume output. Amylase secretion into the pancreatic juice was measured according to the method of Street and Close, ${ }^{13}$ protein content of the pancreatic juice according to the method of Lowry et al. ${ }^{14}$ Whole blood concentrations of cyclosporin A were measured with the TDx fluorescent polarisation immunoassay (Abbott Diagnostics, Germany) according to the method of Schroeder et al. ${ }^{15}$ Enzyme determinations were done immediately after the end of the experiments. Radioimmunoassays of insulin and cyclosporin A were performed after storage of the samples at $-20^{\circ} \mathrm{C}$ within two weeks after the experiments were done.

\section{STATISTICAL ANALYSIS}

Results are expressed as mean (SEM). Comparisons between different groups of data were made using Student's $t$ test for unpaired data and differences with $\mathrm{p}$ values $<0.05$ were considered significant.

\section{Results}

EFFECTS OF CYCLOSPORIN A AND/OR INDOMETHACIN ON GLUCOSE DEPENDENT INSULIN RELEASE

Treatment with cyclosporin A ( 5 or $10 \mathrm{mg} / \mathrm{kg}$ ) alone significantly reduced $(p<0.05$ and $\mathrm{p}<0.001$, resp) insulin release. Treatment with indomethacin ( $2 \mathrm{mg} / \mathrm{kg}$ ) had no significant influence on insulin release. Combined administration of cyclosporin $\mathrm{A}$ and indomethacin caused a further significant decrease of insulin release as compared with cyclosporin A treated rats only (cyclosporin A $5 \mathrm{mg} / \mathrm{kg} 1091$ (187) $\mu \mathrm{U}$ $v$ cyclosporin A $5 \mathrm{mg} / \mathrm{kg}$ + indomethacin 490 (70) $\mu \mathrm{U}, \mathrm{p}<0.01$; cyclosporin A $10 \mathrm{mg} / \mathrm{kg} 447$ (44) $\mu \mathrm{U} v$ cyclosporin $\mathrm{A} 10 \mathrm{mg} / \mathrm{kg}+$ indomethacin $222(60) \mu \mathrm{U}, \mathrm{p}<0.01$; Fig 1 ).

\section{EFFECTS OF CYCLOSPORIN A AND/OR INDOMETHACIN ON CHOLECYSTOKININ-8 STIMULATED AMYLASE SECRETION}

Amylase secretion was not clearly affected after treatment with $5 \mathrm{mg} / \mathrm{kg}$ cyclosporin $\mathrm{A}$ alone. $10 \mathrm{mg} / \mathrm{kg}$ cyclosporin A alone significantly $(\mathrm{p}<0.05)$ reduced amylase secretion. While indomethacin alone did not affect amylase secretion, together with cyclosporin $A$ it caused significant $(\mathrm{p}<0.01 v$ controls) inhibition of enzyme secretion (Fig 2).

\section{EFFECTS OF CYCLOSPORIN A AND/OR} INDOMETHACIN ON CHOLECYSTOKININ-8 STIMULATED PROTEIN CONTENT OF THE EXOCRINE JUICE

Pancreatic juice protein content was not reduced after treatment with $5 \mathrm{mg} / \mathrm{kg}$ cyclosporin $\mathrm{A}$, but was significantly reduced after $10 \mathrm{mg} / \mathrm{kg}$ cyclosporin $A(p<0.001)$. Indomethacin given alone 


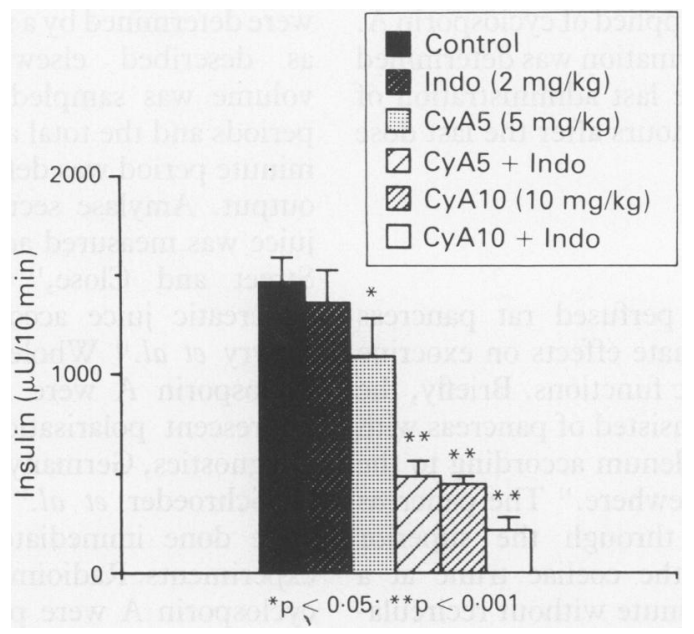

Figure 1: Effect of 5 and $10 \mathrm{mg} / \mathrm{kg}$ cyclosporin $A$ and/or $2 \mathrm{mg} /$ $\mathrm{kg}$ indomethacin on insulin release during isolated arterial perfusion of the pancreas with $15.8 \mathrm{mM}$ glucose (mean (SEM); $n=10-12$ per group): Significant decrease of insulin release at 5 and $10 \mathrm{mg} / \mathrm{kg}$ cyclosporin $A(p<0.05$ and $p<0.001)$, and more severe impairment after additional treatment with indomethacin $(p<0.01 \mathrm{v}$ each other; $p<0.001$ $\mathrm{v}$ controls). Indo=indomethacin, $C y A=$ cyclosporin $A$

had no significant effect. Cyclosporin A applied together with indomethacin significantly decreased pancreatic juice protein content with both doses used $(5 \mathrm{mg} / \mathrm{kg}$ cyclosporin $\mathrm{A}+$ indomethacin $\mathrm{p}<0.05 ; 10 \mathrm{mg} / \mathrm{kg}$ cyclosporin $\mathrm{A}+$ indomethacin $\mathrm{p}<0.001 ; \mathrm{p} v$ controls; Fig 3).

\section{EFFECTS OF CYCLOSPORIN A AND/OR} INDOMETHACIN ON THE EXOCRINE PANCREATIC VOLUME OUTPUT

Both doses of cyclosporin A did not diminish the volume output (control $29.6(5.6) \mu \mathrm{l}, 5 \mathrm{mg} / \mathrm{kg}$ cyclosporin A $26.6(5.9) \mu \mathrm{l}$, and $10 \mathrm{mg} / \mathrm{kg}$ cyclosporin A $27 \cdot 0(5 \cdot 3) \mu \mathrm{l})$. Indomethacin alone caused a significant reduction of the volume output $(18.6(2.2) \mu \mathrm{l}, \mathrm{p}<0.05)$. Indomethacin plus 5 or $10 \mathrm{mg} / \mathrm{kg}$ cyclosporin A tended to further decrease volume output $(5 \mathrm{mg} /$ $\mathrm{kg}$ cyclosporin A+indomethacin 14.0 (3.1) $\mu \mathrm{l}$, $\mathrm{p}<0.01 v$ controls; $10 \mathrm{mg} / \mathrm{kg}$ cyclosporin $\mathrm{A}+$ indomethacin $12.2(2.2) \mu \mathrm{l}, \mathrm{p}<0.01 v$ controls). Differences between indomethacin treated and indomethacin + cyclosporin A treated rats, however, did not reach statistical significance.

Figure 2: Effect of 5 and 10 $\mathrm{mg} / \mathrm{kg}$ cyclosporin $A$ and/or 2 $\mathrm{mg} / \mathrm{kg}$ indomethacin on mg/kg indomethacin on
cholecystokinin-8 stimulated (100 pg/ml) amylase secretion in the presence of $15 \cdot 8 \mathrm{mM}$ glucose (mean (SEM); $n=10-12$ per group): Significant decrease of amylase secretion in rats treated with $10 \mathrm{mg} / \mathrm{kg}$ cyclosporin A alone $(p<0.05)$ and at both doses of cyclosporin A after additional treatment with indomethacin $(p<0.01 \mathrm{v}$ controls). CCK $-8=$ cholecystokinin-8.

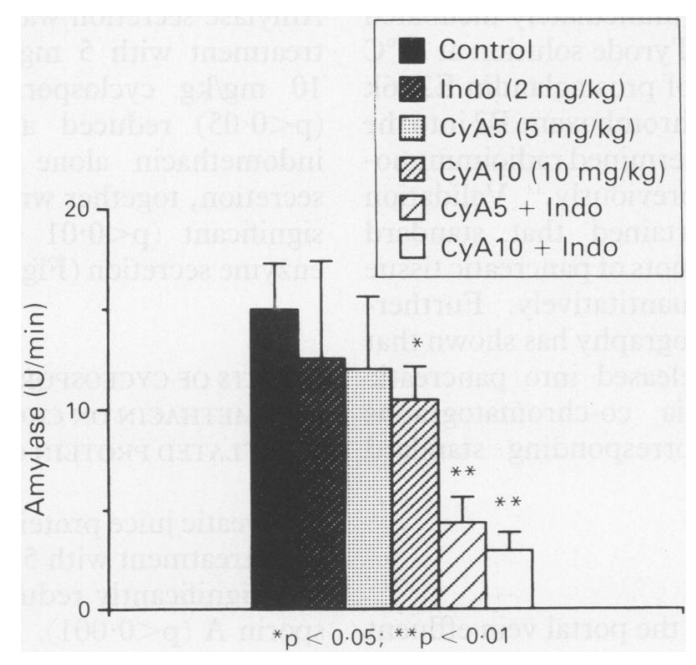

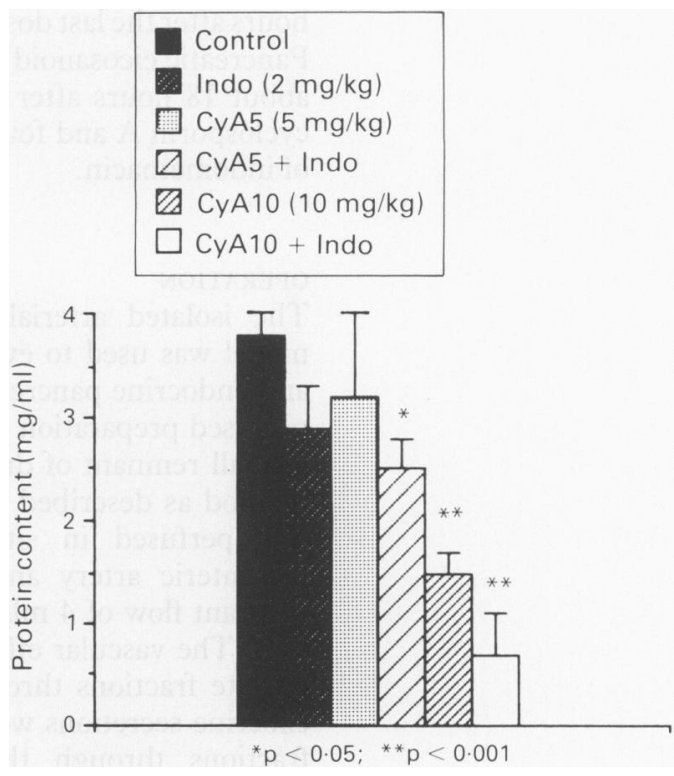

Figure 3: Total protein content in pancreatic juice during stimulation with $100 \mathrm{pg} / \mathrm{ml}$ cholecystokinin-8 in the presence of $15.8 \mathrm{mM}$ glucose in rats treated with 5 and $10 \mathrm{mg} / \mathrm{kg}$ cyclosporin $A$ and/or $2 \mathrm{mg} / \mathrm{kg}$ indomethacin (mean (SEM); $n=10-12$ per group): Significant decrease of protein content at $10 \mathrm{mg} / \mathrm{kg}$ cyclosporin $A(p<0.05)$ and at both doses of cyclosporin $A$ after additional treatment with indomethacin $(p<0.001$ v controls $)$.

EFFECTS OF INDOMETHACIN ON WHOLE BLOOD CONCENTRATIONS OF CYCLOSPORIN A

Treatment with 5 or $10 \mathrm{mg} / \mathrm{kg}$ cyclosporin A once daily for eight days resulted in blood concentrations of $401(88) \mathrm{ng} / \mathrm{ml}$ and $1353(145)$ $\mathrm{ng} / \mathrm{ml}$, resp, 24 hours after the last dose. In rats with combined treatment with indomethacin and cyclosporin A over the same period cyclosporin A blood concentrations were significantly higher than in rats treated with the corresponding dose of cyclosporin A only (Fig 4).

\section{EFFECTS OF CYCLOSPORIN A AND/OR}

INDOMETHACIN ON SYNTHESIS OF

PROSTAGLANDINS AND THROMBOXANE B2 BY

PANCREATIC TISSUE EX VIVO

As shown in Figure 5, treatment with cyclosporin A ( 5 or $10 \mathrm{mg} / \mathrm{kg}$ for eight days) did not affect synthesis of prostaglandin E2, 6k prostaglandin F1a, and thromboxane B2 by pancreatic tissue ex vivo. Formation of all three eicosanoids was inhibited after treatment with indomethacin $(2 \mathrm{mg} / \mathrm{kg}$ ) for eight days. Inhibition of eicosanoid formation after combined administration of indomethacin and cyclosporin A (5 or $10 \mathrm{mg} / \mathrm{kg}$ ) was not more pronounced than after indomethacin alone.

\section{Discussion}

This study confirms previous reports of our group $^{5}$ and others ${ }^{16}$ that immunosuppressive doses of cyclosporin $A^{17}$ impair endocrine and exocrine pancreatic functions in rats. While the glucose dependent insulin release was reduced by treatment with 5 and $10 \mathrm{mg} / \mathrm{kg}$ cyclosporin A for eight days, the cholecystokinin-8 stimulated amylase secretion was only impaired at the higher dose of $10 \mathrm{mg} / \mathrm{kg}$ cyclosporin $\mathrm{A}$. Insulin 


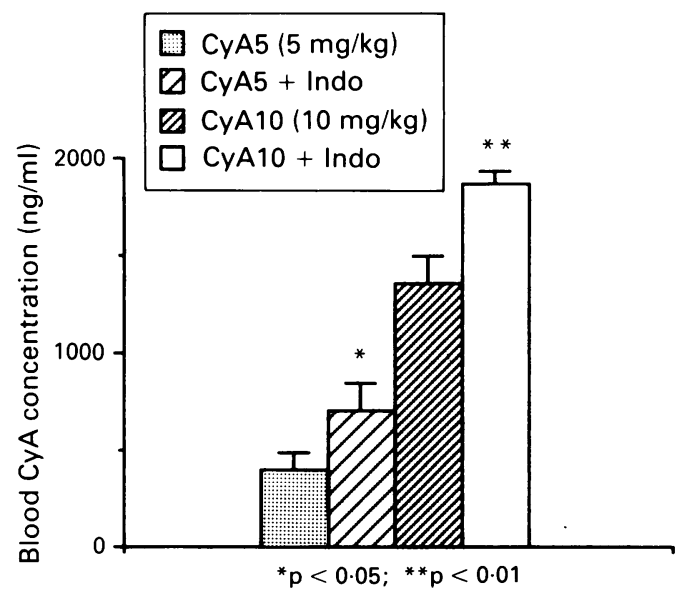

Figure 4: Relationship between intragastrically applied 5 and $10 \mathrm{mg} / \mathrm{kg}$ cyclosporin $A$ and whole blood concentrations of cyclosporin A determined 24 hours after the last application (measurement with the TDX fluorescent polarisation immunoassay; mean (SEM); $n=10-12$ per group): Significant increase of cyclosporin A blood concentrations after additional application of cyclosporin A treated rats with $2 \mathrm{mg}$ $k g$ indomethacin $(p<0.05$ and $p<0.01$, resp, v rats treated with the corresponding cyclosporin $A$ dose only).

promotes the synthesis of amylase by a direct effect on exocrine pancreatic cells via the insuloacinar axis. ${ }^{18}$ Whether the noxious effect of cyclosporin A on amylase secretion is the consequence of reduced insulin release, is not known.

Treatment with indomethacin at a dose of $2 \mathrm{mg} / \mathrm{kg}$ twice daily had no influence on pancreatic functions. Indomethacin treatment, however, significantly aggravated the toxic action of cyclosporin $\mathrm{A}$ on the endocrine and exocrine pancreas. Reports on the effect of cyclosporin A on prostaglandin synthesis in the kidney are controversial. ${ }^{19-21}$ Most studies have, however, reported that cyclosporin A comparably inhibited renal prostaglandin formation. In con- trast, treatment of rats with 5 or $10 \mathrm{mg} / \mathrm{kg}$ cyclosporin $\mathrm{A}$ in our study did not reduce the ex vivo synthesis of prostaglandin $\mathrm{E} 2,6 \mathrm{k}$ prostaglandin $F 1 \alpha$, and thromboxane B2 by pancreatic tissue. The more pronounced inhibition of formation of thromboxane B2 as compared with formation of $6 \mathrm{k}$ prostaglandin $\mathrm{F} 1 \alpha$ and particularly prostaglandin E2 may be the result of different cellular sources of the eicosanoids studied. Thus, thromboxane B2 released during incubation of pancreatic fragments may be derived mainly from trapped platelets which are known to be particularly sensitive to the effect of cyclooxygenase inhibitors.

Although the time interval between the last dose of cyclosporin A and the assessment of pancreatic eicosanoid formation was 18 hours, this cannot explain the lack of inhibitory action of cyclosporin A on pancreatic eicosanoid formation. High concentrations of circulating cyclosporin A have been measured in our study 24 hours after the last dose of cyclosporin A. Furthermore, tissue concentrations of cyclosporin $A$ in the pancreas are still high after such a period of time. ${ }^{5}$ Indomethacin in the dose used significantly reduced eicosanoid formation in the pancreas ex vivo. Combined treatment with indomethacin and cyclosporin A did not further increase the inhibitory action of indomethacin on pancreatic eicosanoid formation. This finding supports the concept that cyclosporin A has no inhibitory action on pancreatic prostaglandin and thromboxane formation under the experimental conditions used.

The discrepancy of our results to the reported inhibitory action of cyclosporin A on renal prostaglandin formation may be caused by an organ selective effect of cyclosporin $A$ or to the higher doses of cyclosporin $A$ - that is, $50 \mathrm{mg} / \mathrm{kg}$, used in studies on renal prostaglandin formation. ${ }^{17}$
Figure 5a-c: Effect of $2 \mathrm{mg} /$ $\mathrm{kg}$ indomethacin andlor 5 and $10 \mathrm{mg} / \mathrm{kg}$ cyclosporin $A$ on pancreatic eicosanoid formation ex vivo (mean (SEM); $n=10-12$ per group): Significant inhibition with $2 \mathrm{mg} / \mathrm{kg}$ indomethacin for prostaglandin E2, $6 k$ prostaglandin $F 1 \alpha$, and thromboxane $B 2(p<0.05$, $<0.01$, and $<0.005$, resp, $\mathrm{v}$ controls). Both doses of cyclosporin A given alone have no influence ( $p \mathrm{v}$ controls) on pancreatic eicosanoid formation. Combined treatment with cyclosporin $A$ and indomethacin has no further significant inhibitory action as compared with indomethacin alone on pancreatic eicosanoid formation ( $p \mathrm{v}$ indomethacin). $P G=$ prostaglandin; $T X=$ thromboxane.
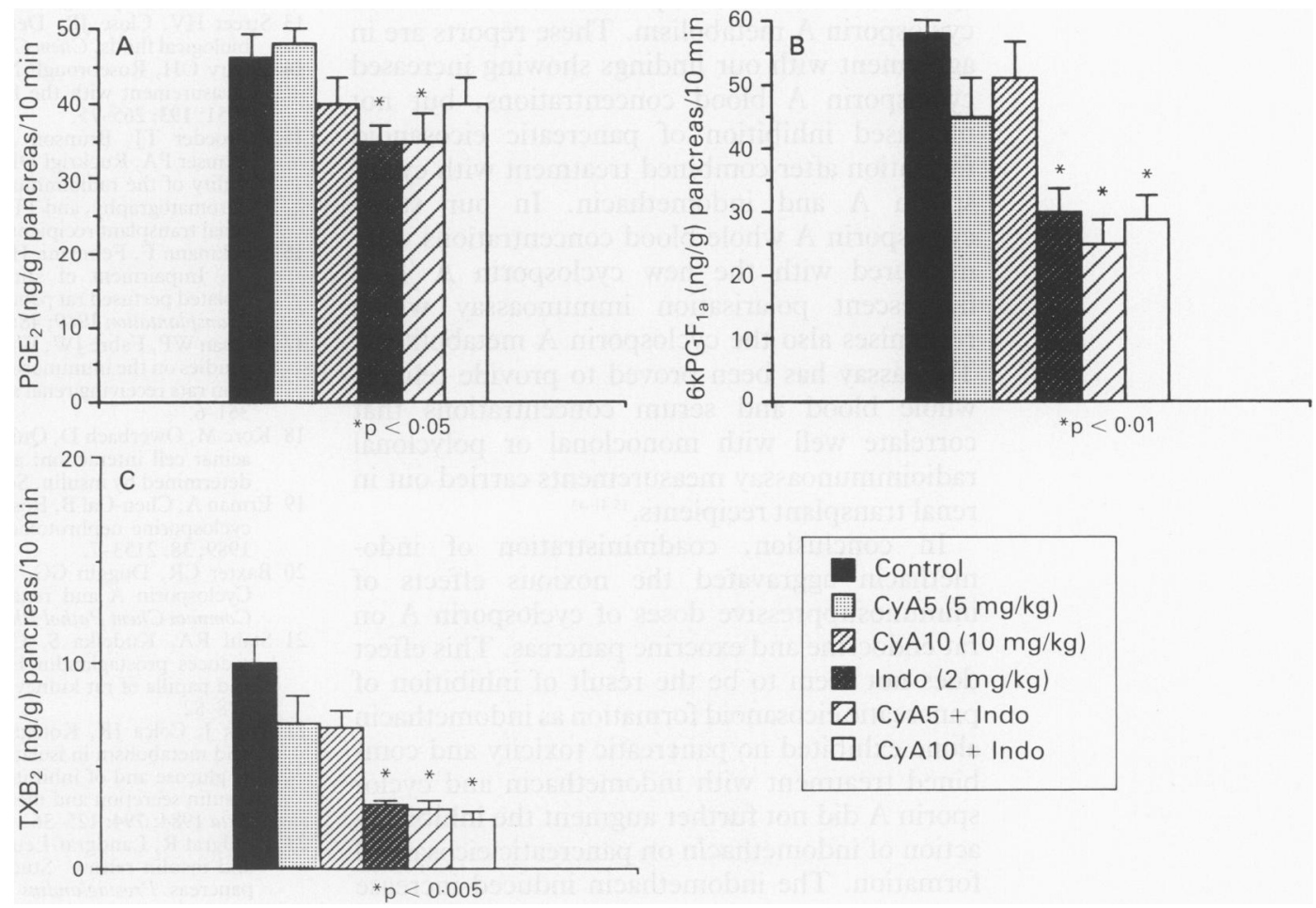
Administration of indomethacin caused no decrease in the glucose induced insulin release in our preparation confirming previous studies. ${ }^{22-24}$ Investigations in man have shown controversial results. Thus, treatment with cyclooxygenase inhibitors has been reported to augment ${ }^{25-27}$ or to suppress ${ }^{28}$ glucose induced insulin release. In our investigations, cholecystokinin- 8 induced amylase secretion and total protein content of the pancreatic juice were not altered by indomethacin, findings that are in agreement with studies in $\operatorname{man}^{29}$ and dogs. ${ }^{30}$ We have not studied whether indomethacin affects arterial blood flow. A dose of $5 \mathrm{mg} / \mathrm{kg}$ indomethacin has, however, been reported to be without influence on pancreatic arterial blood flow. ${ }^{31}$ It is therefore not likely that the aggravation of cyclosporin $\mathrm{A}$ induced pancreatic toxicity by indomethacin is caused by vascular effects. When two potentially toxic agents are coadministered the resultant toxicity may be greater than that observed with either agent when given alone. Treatment with the immunosuppressive agent cyclosporin $\mathrm{A}$ is associated with pancreatotoxicity, ${ }^{10}$ nephrotoxicity, ${ }^{832}$. and hepatotoxicity. ${ }^{33-36}$ Other agents that alter the degree of cyclosporin $\mathrm{A}$ induced toxicity - that is, nephrotoxicity, have been suggested to act by altering circulating cyclosporin A blood concentrations as a consequence of induction or inhibition of cytochrome P-450 dependent (new nomenclature: P-450IIIA; 36) hepatic drug metabolism. ${ }^{37}{ }^{38}$ Both cyclosporin A and indomethacin are known to decrease cytochrome P-450 dependent monooxygenase activity in primary cultures of hepatocytes of rats, ${ }^{9}{ }^{37-40}$ rabbits, and man, ${ }^{36}$ although the mechanism whereby cyclosporin A causes the decrease is not known. The hepatic monooxygenase system is supposed to be involved in the detoxication of cyclosporin A. ${ }^{9}$ Conjoint treatment of rats with cyclosporin $\mathrm{A}$ and indomethacin was found to be associated with increased whole blood concentrations of cyclosporin $\mathrm{A}^{3338}$ as a consequence of the decreased cyclosporin A metabolism. These reports are in agreement with our findings showing increased cyclosporin A blood concentrations, but not increased inhibition of pancreatic eicosanoid formation after combined treatment with cyclosporin A and indomethacin. In our study cyclosporin A whole blood concentrations were measured with the new cyclosporin A TDx fluorescent polarisation immunoassay which recognises also the cyclosporin A metabolites. ${ }^{15}$ This assay has been proved to provide reliable whole blood and serum concentrations that correlate well with monoclonal or polyclonal radioimmunoassay measurements carried out in renal transplant recipients. ${ }^{15+1-43}$

In conclusion, coadministration of indomethacin aggravated the noxious effects of immunosuppressive doses of cyclosporin A on rat endocrine and exocrine pancreas. This effect does not seem to be the result of inhibition of pancreatic eicosanoid formation as indomethacin alone exhibited no pancreatic toxicity and combined treatment with indomethacin and cyclosporin A did not further augment the inhibitory action of indomethacin on pancreatic eicosanoid formation. The indomethacin induced increase in cyclosporin A toxicity to the pancreas is associated with raised whole blood concentrations of cyclosporin A possibly resulting from an interference with P-450 dependent hepatic drug metabolism by indomethacin. Thus, the protection conferred by administration of exogenous prostaglandins of the E-series ${ }^{10}$ may not be caused by substitution of endogenous prostaglandins, but involves other as yet unknown mechanisms. Finally, the possibility that coadministration of non-steroidal antiinflammatory drugs results in increased toxic effects in cyclosporin A treated patients should be considered.

We are grateful to $M$ Beste and $J$ Hüber for excellent technical assistance. This work was supported by DFG grant Mu 543/3-4.

1 Starzl TE. Clinical aspects of cyclosporine therapy: a summation. Transplant Proc 1983; 15 (suppl 1): 3103-7.

2 Keown PA, Stiller CR, Ulan RA, Sinclair NR, Wall WJ. Immunological and pharmacological monitoring in the clinical use of cyclosporin A. Lancet 1981; i: 686-9.

3 Ota B, Bradley M. Side effects of cyclosporine in 100 renal allograft recipients. Transplant Proc 1983; 15 (suppl 2): 3150-6.

4 Myers BD, Ross J, Newton L, Luetscher J, Perlroth M Cyclosporine-associated chronic nephropathy. $N$ Engl f Med 1984; 311: 699-705.

5 Müller MK, Bergmann K, Degenhardt H, Klöppel G, Löh $\mathrm{M}$, Coone $\mathrm{HJ}$, et al. Differential sensivity of rat exocrine and endocrine pancreas to cyclosporine. Transplantation 1988; 45: 698-700.

6 Helmchen U, Schmidt WE, Siegel EG, Creutzfeldt W. Morphological and functional changes of pancreatic B cells Morphological and functional changes of pancreatic B cells

7 Yale JF, Roy RD, Grose M, Seemayer TA, Murphy GF, Marliss EB. Effects of cyclosporine on glucose tolerance in he rat. Diabetes 1985; 34: 1309-13.

8 Ryffel B, Donatsch P, Hiestand P, Mihatsch MJ. PGE2 reduces nephrotoxicity and immunosuppression of cyclosporine in rats. Clin Nephrol 1986; 25 (suppl 1): S95-9.

9 Cunningham C, Burke MD, Wheatley DN, Thomson AW Simpson JG, Whiting PH. Amelioration of cyclosporininduced nephrotoxicity in rats by induction of hepatic drug metabolism. Biochem Pharmacol 1985; 34: 573-8.

10 Müller MK, Degenhardt H, Klöppel G, Goebell H, Bergmann $\mathrm{K}$, Löhr M. Prevention of toxic effects of cyclosporin on pancreatic B-cells of rats by Rioprostil, a new prostaglandin pancreatic B-cells of rats by Riop

11 Müller MK, Demol P, Fladrich G, Goebell H, Pederson RA Glucose-dependent insulinotropic action of cholecystokinin octapeptide in the isolated perfused rat pancreas. Digestion 1983; 27: 245-51.

12 Peskar BM, Hoppe U, Lange K, Peskar BA. Effects of non steroidal anti-inflammatory drugs on rat gastric mucosa leukotriene $\mathrm{C} 4$ and prostanoid release: relation to ethanolinduced injury. Br f Pharmacol 1988; 93: 937-43.

13 Street HV, Close JR. Determination of amylase activity in biological fluids. Chem Clin Acta 1956; 1: 256-62.

14 Lowry OH, Rosebrough NJ, Farr AL, Randall RJ. Protein measurement with the folin phenol reagent. 7 Biol Chem 1951; 193: 265-75.

15 Schroeder TJ, Brunson ME, Pesce AJ, Hindenlang LL Mauser PA, Ruckrigl DI, et al. A comparison of the clinical utility of the radioimmuno-assay, high-performance liquid chromatography, and TDx cyclosporine assays in outpatient chromatography, and TDx cyclosporine assays in outpatient
renal transplant recipients. Transplantation 1989; 47: 262-6. renal transplant recipients. Transplantation 1989; 47: 262-6.
Stöckmann F, Fehmann HC, Göke B, Siegel EG, Creutzfeldt W. Impairment of stimulated insulin release from the isolated perfused rat pancreas by cyclosporine pretreatment. Transplantation 1989; 48: 381-5.

17 Homan WP, Fabre JW, Williams KA, Millard PR, Morris PJ Studies on the immunosuppressive properties of cyclosporin A in rats receiving renal allografts. Transplantation 1980;29. $361-6$.

18 Korc M, Owerbach D, Quinto C, Rutter WJ. Pancreatic isletacinar cell interaction: amylase messenger RNA levels are determined by insulin. Science 1981; 213: 351-3.

19 Erman A, Chen-Gal B, Rosenfeld J. The role of eicosanoids in cyclosporine nephrotoxicity in the rat. Biochem Pharmacol 1989; 38: 2153-7.

20 Baxter CR, Duggin GG, Horvath JS, Hall BM, Tiller DJ. Cyclosporin A and renal prostaglandin biosynthesis. $R$. Commun Chem Pathol Pharmacol 1984; 45: 69-80.

21 Stahl RA, Kudelka S. Chronic cyclosporine A treatment reduces prostaglandin E2 formation in isolated glomeruli and papilla of rat kidneys. Clin Nephrol 1986; 25 (suppl 1): S78-82

22 Turk J, Colca JR, Kotagal N, McDaniel ML. Arachidonic acid metabolism in isolated pancreatic islets. II. The effects of glucose and of inhibitors of arachidonate metabolism on insulin secretion and metabolite synthesis. Biochim Biophys Acta 1984; 794: 125-36.

23 Landgraf R, Landgraf-Leurs MM. The prostaglandin system and insulin release. Studies with the isolated perfused rat pancreas. Prostaglandins 1979; 17: 599-613. 
24 Spangler RS, Pek SB. Effects of cyclooxygenase inhibition on prostaglandin production and insulin and glucagon secretion by isolated rat islets. Adv Prostaglandin Thromboxane Leukotriene Res 1983; 12: 291-7.

25 McRae JR, Metz SA, Robertson RP. A role for endogenous prostaglandins in defective glucose potentiation of nonglucose insulin secretagogues in diabetics. Metabolism 1981 30: 1065-75.

26 Giugliano D, Sgamboto S, Coppola L, Misso L, Torella R. Impaired insulin secretion in human diabetes mellitus. II. A pos-

27 Metz SA, Fujimoto WY, Robertson RP. A role for prostaglandins as mediators of alpha-adrenergic inhibition of the acute insulin response to glucose. Adv Prostaglandin Thromboxane Res 1980; 8: $1291-4$.

28 Topol E, Brodows RG. Effects of indomethacin on acute insulin release in man. Diabetes $1980 ; 29: 379-82$.

29 Saad C, Dooley CP, Valenzuela JE. Effect of 15(R), 15-methyl prostaglandin E2 and indomethacin on pancreatic secretion in man. Dig Dis Sci 1987; 32: 487-93.

30 Homma T, Malik KU. Effect of secretin and caerulein in canine pancreas: relation to prostaglandins. Am $\mathcal{f}$ Physio

31 Studley JG, Lee JB, Schenk WG Jr. Effects of indomethacin on blood flow in the normal pancreas in conscious dogs. f Surg Res 1984; 37: 464-6.

32 Ryffel B, Donatsch P, Madörin M, Matter BE, Ruttimann G, Schon $\mathrm{H}$, et al. Toxicological evaluation of cyclosporin A Arch Toxicol 1983; 53: 107-41.

33 Cunningham C, Gavin MP. Whiting PH, Burke MD, Macintyre F, Thomson AW, et al. Serum cyclosporin levels, hepatic drug metabolism and renal tubulotoxicity. Biochem Pharmacol 1984; 33: 2857-61.

34 Moochhala SM, Renton KW. Inhibition of hepatic microsomal drug metabolism by the immunosuppressive agent somal drug metabolism by the immunosuppressive ag
cyclosporin A. Biochem Pharmacol 1986; 35: 1499-503.

35 Augustine JA, Zemaitis MA. The effects of cyclosporin A (CsA) on hepatic microsomal drug metabolism in the rat. Drug Metab Dispos 1986; 14: 73-8.
36 Nebert DW, Nelson DR, Adesnik M, Coon MJ, Estabrook RW, Gonzalez FJ, et al. The P-450 superfamily: updated listing of all genes and recommended nomenclature for the chromosomal loci. DNA 1989; 8: 1-13.

37 Burke MD, Whiting PH. The role of drug metabolism in cyclosporine A nephrotoxicity. Clin Nephrol 1986; 25 (suppl 1): S111-6.

38 Whiting PH, Barnard M, Neilsch A, Simpson JG, Burke MD. Interactions between cyclosporin $A$, indomethacin and 16,16-dimethyl prostaglandin E2: effects on renal, hepatic and gastrointestinal toxicity in the rat. BrF Exp Pathol 1987; 68: 777-86.

39 Pichard L, Fabre I, Fabre G, Domergue J, Saint Aubert B, Mourad G, et al. Cyclosporin A drug interactions. Screening for inducers and inhibitors of cytochrome P-450 (cyclosporin A oxidase) in primary cultures of human hepatocytes and in liver microsomes. Drug Metab Dispos 1990; 18: 595606.

40 Falzon M, Milton AS, Burke MD. Are the decreases in hepatic cytochrome P-450 and other drug-metabolising enzymes cytochrome $\mathrm{P}-450$ and other drug-metabolising enzymes caused by indomethacin in vivo mediated by intestinal
bacterial endotoxins? 16,16-Dimethyl-prostaglandin F2 bacterial endotoxins? 16,16-Dimethyl-prostaglandin F2
alpha prevents decreases in hepatic drug-metabolising enzymes due to exogenous endotoxin. Biochem Pharmacol 1984; 33: 1285-92.

41 Schleuter KT, Wermeling JR, Schroeder TJ, Pesce AJ, Hassan $M$, Warner A. Cross reactivity of cyclosporine $A$ and metabolite ' $\mathrm{M} 17$ ' in fluorescence polarization immunoassay. Clin Chem 1988; 34: 1262-3.

42 Clardy CW, Schroeder TJ, Myre SA, Wadhwa NK, Pesce AJ, First MR, et al. Clinical variability of cyclosporine pharmacokinetics in adult and pediatric patients after renal, cardiac, hepatic, and bone-marrow transplants. Clin Chem 1988; 34: 2012-5.

43 National Academy of Clinical Biochemistry/American Association for Clinical Chemistry Task Force on Cyclosporine Monitoring. Critical issues in cyclosporine monitoring: Report of the Task Force on Cyclosporine Monitoring. Clin Chem 1987; 33: 1269-88. 